\title{
Analisis Komunikasi Visual Pada Poster Sebagai Media Komunikasi Mendorong Jarak Sosial Di Jakarta Saat Epidemi Covid 19
}

\author{
Arsa Widitiarsa Utoyo \\ New Media Program, Visual Communication Design Department, School of Design, Bina Nusantara University \\ email : Arsa_w@binus.ac.id
}

\begin{tabular}{ll}
\hline ARTICLE INFO & ABSTRACT \\
\hline & Health campaigns about the covid 19 epidemic need to underlined as important \\
actions to prevent viruses that cause fever, coughing, shortness of breath, chest \\
pain and death. The health ministry and the local government need to move public \\
awareness about healthy lifestyle. This research has analysed the key elements of \\
health campaign posters in Jakarta. The Poster is still an active platform to tell \\
data, schedules, display information, to persuade citizen in Jakarta. This study \\
uses a qualitative approach, and uses case studies to visual analysis of local \\
content and national poster design in Jakarta. The results show that local and \\
national poster designs have different elements of the design, and it affects \\
different posters. The results show that local and national poster designs have \\
different colour, font, title, blank space, size and visual aids of the design results \\
that affect different posters.
\end{tabular}

\section{PENDAHULUAN}

Poster didefinisikan sebagai format dua dimensi, halaman tunggal untuk menginformasikan informasi tampilan, data, jadwal, atau penawaran dan untuk meyakinkan orang, penyebab, tempat, acara, produk, perusahaan, layanan, kelompok atau organisasi. Ini diproduksi secara masifdan biasanya dapat dengan mudah dilihat diberbagai media di kota Jakarta seperti di pintu masuk menuju tempat wisata maupun di perumahan dan perkantoran.

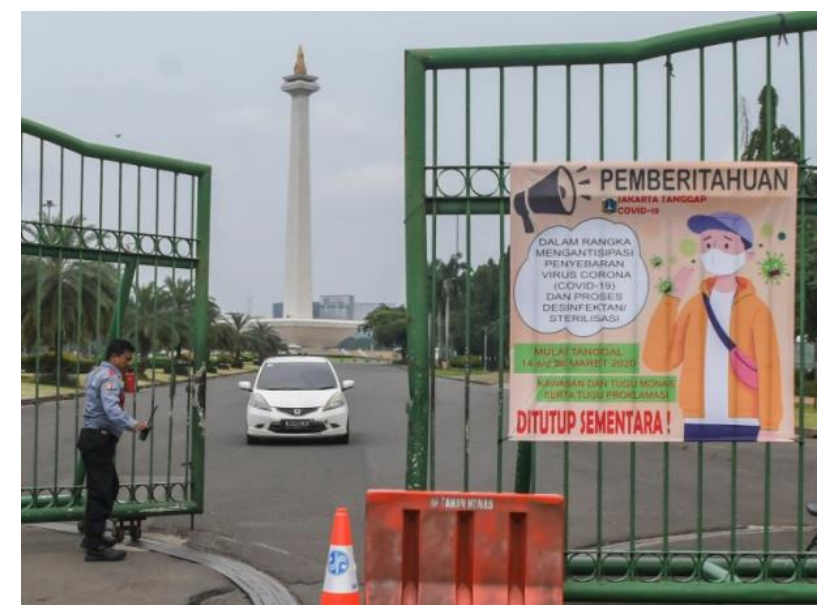

Gambar 1: Poster di pintu masuk menuju monas

Ubiquity dan beberapa alamat tontonan untuk banyak pemirsa dan memperkuat pesan untuk pemirsa secara individual (Landa, 2013). Poster adalah bentuk seni publik yang kuat dan berpengaruh, dan mereka menarik memperhatikan dan mendistribusikan informasi kepada masyarakat luas, beragam dan selalu berubah (Carter, 2008). Sangat penting untuk merancang poster yang mempertimbangkan elemen kunci di dalam poster desain untuk hasil yang berdampak (Hess, 2013). 
Dalam membuat poster ada beberapa elemen yang harus dipertimbangkan desainer. Poster harus dirancang untuk menarik perhatian dan berinteraksi informasi secara efektif. Secara manipulatif, poster dan mata efektif untuk seni dan perencanaan yang cermat terjadi. Enam prinsip desain harus diterapkan dalam desain poster seperti font, warna, judul, ukuran dan ruang kosong, ukuran poster dan grafik. Melihat penggunaan font harap hindari menggunakan font skrip mewah karena mereka dapat membuat poster sulit dibaca (Girard, 2012).

Warna harus cerah saat membuat poster menurut Chester F. Carlson Center dari ilmu visual. Warna gelap memantulkan lebih sedikit cahaya daripada warna cerah dan itu membuat poster lebih sulit untuk dibaca. Judul seharusnya pendek dan sederhana; orang-orang harus dapat membaca judul poster anda dari jarak 4 hingga 6 meter. Lain elemen yang merupakan ruang putih membuat pemindaian informasi poster lebih mudah. Selain itu, ruang kosong harus dibiarkan di sekitar ruang lingkup poster untuk membuat bingkai putih divisi untuk poster seperti yang banyak dibuat oleh beberapa Universitas. Akhirnya, penggunaan alat bantu visual, seperti grafik, bagan dan foto adalah untuk berkomunikasi pesan dari poster agar lebih efektif, tetapi menggunakan terlalu banyak alat bantu visual dapat membuat poster membingungkan.

Alat bantu visual harus lebih besar dari bagian poster yang lain agar mudah dibaca (Girard, 2012). Melihat sisi iklan, sangat penting untuk mengetahui bagaimana desain iklan dapat menjadi sangat efektif dalam menangkap mata konsumen individu berdasarkan pada seberapa tepat elemen-elemen desain seperti gambar, teks dan warna dipilih dan disatukan dalam iklan produk. Konsentrasi disetiap kata pada poster harus diperlukan untuk memahami pesan poster dan harus khusus sebatas mungkin. Menarik adalah kriteria lain dalam poster yang harus terlihat menyenangkan dan menarik, dan itu harus memperhatikan perhatian khalayak, dan penampilannya tidak boleh mengalihkan perhatian dari pesan itu sendiri. Kesederhanaan biasanya yang terbaik. Terakhir, keterbacaan sangat penting karena huruf harus cukup besar dan untuk pemirsa yang lebih tua berdiri pada jarak 1 hingga 2 meter.

Sangat menarik untuk dapat mengurangi ukuran font yang diizinkan untuk informasi lebih lanjut tentang poster, tetapi ini akan mencegah orang yang lewat atau melihat sekilas. Elemen adalah unsut penting dalam membuat poster, dalam sebuah artikel disebutkan bahwa, tebal besar, hitam panah dan pointer sepenuhnya hanya hal pertama yang menarik perhatian. Lebih khusus lagi, untuk beberapa, itu mungkin petunjuk paling signifikan dan paling berani di bagian tengah halaman. Poster yang bermanfaat juga berperan sebagai seni mata. Oleh karena itu, langkah-langkah desain yang tepat untuk membuat tanda yang memadai perlu dilakukan diperhitungkan dengan cermat.

Enam prinsip desain harus ada didalam mendesain poster, yaitu font, warna, judul, pengukuran dan ruang kosong, ukuran poster dan grafik (DeBara, 2018). Melihat ke penggunaan font harap hindari menggunakan font skrip mewah karena mereka dapat membuat poster sulit dibaca. Warna harus cerah saat membuat tanda menurut Pusat Ilmu Gambar Chester F. Carlson.

Warna gelap menunjukkan lebih sedikit cahaya daripada warna cerah, dan itu membuat poster sulit dibaca. Judul harus singkat dan sederhana; orang harus dapat membaca judul poster dari 4 hingga 6 meter jauhnya. Kapan berbicara tentang ruang, ruang putih membuat pemindaian informasi poster lebih mudah sementara ruang kosong harus dibiarkan di sekitar ruang lingkup poster untuk membuat bingkai putih yang mendefinisikan sebagai tanda. Akhirnya, penggunaan alat bantu visual, seperti grafik, gambar dan foto digunakan untuk menyampaikan pesan dari poster secara efisien. Namun, terlalu banyak alat bantu visual dapat membuat kebingungan dalam suatu tanda. Menurut University of North Carolina, panduan subjek menyatakan bahwa, desain elemen poster dibagi menjadi tiga bagian seperti konten, desain dan tata letak dan gambar dan grafik. Bagian utama dari dari poster haruslah konten yang menarik dan mudah dimengerti sehingga poster itu dapat menyajikan informasi yang dapat diterima oleh masyarakat, apa bila tidak dapat menjelaskan informasi yang ingin disampaikan maka poster tersebut tidak akan efektif. Konten yang jelas akan menangkap minat khalayak, konten yang relevan dan signifikan harus dimasukkan ke poster atau akan menjadi hanya pengetahuan umum bukan hal sepele yang menarik. Itu harus menjadi pengetahuan yang relevan dengan khalayak.

Informasi harus penting karena tetap singkat dan berdampak, jika poinnya tidak begitu penting pada selebaran tambahan seperti selebaran atau brosur. Poster yang baik perlu diorganisir dan itu akan menjadi bagus bagian komunikasi. Poster harus jelas dan ringkas sebagai upaya untuk menghindari kata-kata dan jargon, gunakan kata aktif dan kosa kata mudah untuk membuat khalayak mudah dimengerti. Lebih jauh, desain dan tata letak adalah elemen kunci penting dalam mendesain poster yang bagus. Poster harus memiliki judul dan ukuran font harus ekstra 100 poin atau lebih. Kolom adalah bagian terpisah dari desain dan tata letak untuk konten seperti informasi. 
Penjajaran grafik dan heading atau sub informasi harus dengan cara yang benar. Keseimbangan dan jarak yang baik dengan mendistribusikan konten dan gambar di poster agar terlihat berantakan. Ruang putih harus dimasukkan dan cukup atau poster itu akan mengalami kesulitan membaca dan kurang estetika. Konsistensi font, warna dan elemen, ilustrasi dan foto penting. Gunakan font yang sama di poster; gunakan warna serupa untuk poster dan dimensi yang sama untuk ilustrasi dan foto. Gunakan warna dengan bijak akan menambah daya tarik visual di blog Anda poster. Font dan tajuk elemen lain perlu diperhatikan. Dengan hanya menggunakan satu jenis serif font atau san serif akan lebih baik, tetapi sangat bagus untuk menggunakan san serif seperti Arial atau Helvetica untuk judul dan heading.

Jakarta adalah Ibu Kota Negara Indonesia dengan komunitas paling besar dengan total masyarakat sebesar 10.504.000 jiwa. Desain kampanye poster kesehatan sangat langsung dan harus mempunyai dasar informatif yang pasti dan dapat dipertanggung jawabkan. Sebelumnya, desain poster kesehatan Jakarta tidak cukup menarik untuk dapat menarik perhatian orang tua untuk membimbing anak-anak mereka tentang cara memiliki gaya hidup sehat. Poster itu merupakan kampanye yang disampaikan dan menarik bagi khalayak. Pernyataan ini didukung oleh studi percontohan yang telah dilakukan terhadap 50 responden dan target khalayak adalah orang tua dengan anak-anak dengan usia di bawah 35 tahun. Pembelajaran menunjukkan bahwa $86 \%$ responden menjawab 'tidak tertarik pada poster' dan alasannya adalah karena 'pesan yang disampaikan tidak jelas' dan $25 \%$ menyatakan bahwa hurufnya tidak cukup besar.

\section{KERANGKA TEORITIS}

Selama ini banyak terjadi perubahan yang mendasar, salah satunya perubahan dalam dunia media informasi terutama desain poster. Terjadinya perubahan dalam desain poster dapat dilihat dari permasalahan utama yang pemecahannya harus diutamakan. Permasalahan tersebut berkaitan dengan meningkatnya kualitas designer dan juga masyarakat sebagai pembaca maupun penikmat media informasi khususnya poster. Metode membaca poster adalah salah satu bagian dari strategi pembelajaran aktif atau active learning. Metode ini sering juga disebut sebagai metode mengomentari gambar, yakni suatu strategi yang digunakan pendidik dengan maksud mengajak peserta didik untuk memunculkan ide apa yang terkandung dalam suatu gambar, dan tentu saja harus berkaitan dengan pencapaian suatu gambar.

Kompetensi dalam pembelajaran bertujuan untuk menstimulasi dan meningkatkan kreaktifitas dan mendorong penghayatan siswa terhdap suatu permasalahan (Suryani, 2014). Metode ini mendorong siswa untuk bisa mengungkapkan pendapat secara lisan tentang gambar atau poster. Poster adalah media publikasi untuk memberikan informasi kepada masyarakat umum. Poster adalah media grafis atau media visual yang menyajikan kata-kata, kalimat, angka-angka, gambar, dari sumber pesan kepenerima pesan dengan tujuan menarik perhatian, menjelaskan ide melalui proses visualisasi. Poster terdiri dari tulisan, gambar atau penggabungan dari keduanya. Poster dapat dijumpai di berbagai tempat umum karena tujuan utama poster adalah berupa ajakan. Selain itu, poster biasanya dibuat semenarik mungkin misalnya dengan menggunakan background berukuran besar ataupun warna yang mencolok. Hal ini untuk menarik perhatian orang banyak sehingga maksud dari poster dapat cepat tersampaikan.

\section{METODE PENELITIAN}

Penelitian ini adalah penelitian kualitatif, dengan teknik analisis visual isi dari beberapa lokasi di Indonesia yang berdampak cukup besar terhadap penyebaran epidemi covid 19 seperti Jawa Barat, Jawa Timur dan Jawa Tengah yang mempunyai peringkat tinggi dengan masalah penyebaran epidemi covid 19, menurut data yang ditayangkan pada halaman web https://www.covid19.go.id/situasi-virus-corona/. Penelitian ini dilakukan melalui 72 desain poster dari wilayah dengan jumlah kasus covid 19 yang tinggi seperti DKI Jakarta, Jawa Barat, Jawa Timur dan Jawa Tengah dikumpulkan dan dianalisis. Seluruh poster telah dikategorikan berdasarkan penyebab utama mengarah ke masalah covid 19 yang perilaku gaya hidup sehat dan bagaimana aktivitas selama terjadi epidemi covid 19. Selanjutnya, analisis visual dengan elemen-elemen desain seperti warna, font, judul, ruang kosong, ukuran dan visual bantu melanjutkan studi penelitian.

Objek dalam penelitian ini adalah poster edukasi mengenai pencegahan covid 19 secara yang dibuat oleh Kementerian Kesehatan dan disebarkan secara luas di berbagai media di Indonesia dalam 
melakukan strategi komunikasi kampanye Regulasi ini mendapat tanggapan yang beragam dari masyarakat. Dipilihnya DKI Jakarta, Jawa Barat, Jawa Timur dan Jawa Tengah sebagai objek penelitian, karena penyebaran covid 19 yang cukup massif dan juga keberhasilan menyampaikan pesan, memberikan informasi dan persuasi kampanye tersebut sangat tergantung kepada kemampuan strategi komunikasi kampanye yang dilakukan oleh pemerintah.

Cara pengumpulan data dalam melaksanakan penelitian ini adalah sebagai berikut; (1) Observasi dilakukan melalui pengamatan lapangan peran pemerintah dan tim terkait lainnya dalam mensosialisasikan atau upaya persuasi kepada masyarakat terhadap kampanye bahaya covid 19 tersebut. (2) wawancara mendalam: dilakukan dengan bertanya secara langsung kepada informan pemerintah dan stakeholder terkait dengan menggunakan pertanyaan terbuka sehingga mendapatkan penjelasan dan keterangan yang sebenamya. (3) dokumentasi: mengumpulkan dokumen-dokumen tentang perencanaan program, langkah-langkah pelaksanaan, serta catatan kegiatan lainnya yang dilakukan pemerintah dan stakeholder terkait sosialisasi mengenai covid 19.

Teknik analisa data yang akan digunakan peneliti dalam penelitian ini adalah analisis kualitatif, dimana penelitian ini lebih pada analisis individu, serta analisis kemampuan pemerintah untuk melakukan upaya persuasi kepada masyarakat, sejauh mana upaya persuasi pemerintah untuk memberikan informasi, sosialisasi mengenai covid 19 kepada masyarakat sehingga sosialisasi tersebut dapat dipahami dan dimengerti oleh masyarakat.

\section{HASIL PENELITIAN DAN DISKUSI}

\subsection{Analisis Visual Konten: Taksonomi Desain Poster}

Analisis visual menggukan analisis konten berdasarkan pada enam element desain yaitu warna, font, judul, ruang kosong, ukuran dan alat peraga. Pada gambar 2 adalah poster edukasi mengenai pencegahan covid 19 yang secara luas dibuat oleh Kementerian Kesehatan, dan disebarkan secara luas ke berbagai media di Indonesia. Dua kategori dibagi menjadi kategori gaya hidup sehat dan kampanye untuk tetap dirumah.

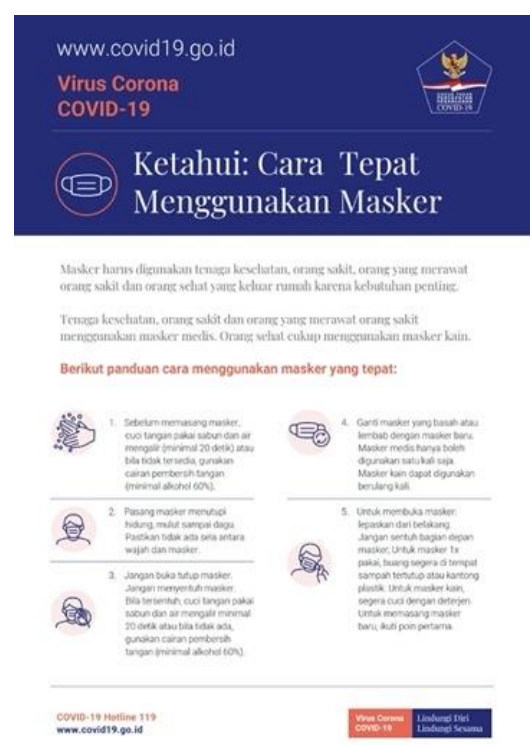

Gambar 2 Ketahui cara tepat menggunakan masker

Ada total 30 poster kampanye mengenai covid 19, dengan berbagai informasi, seperti etika batuk, jaga diri dan keluarga, panduan apabila sakit, menjaga jarak antar warga, cara menggunakan masker, cuci tangan menggunakan sabun, dirumah aja. Ringkasan hasil analisis data dalam berbagai bentuk fisik poster kampanye di Jakarta, memiliki konsep kampanye tertinggi yaitu 78\% lebih tinggi dibandingkan dengan poster di Jawa Barat sebesar 33\% dan Jawa Tengah sebesar 75\%. 
Gambar 3 menunjukkan poster kampanye untuk tetap produktif dirumah yang diterapkan oleh masing-masing wilayah DKI Jakarta, Jawa Barat dan Jawa Tengah.

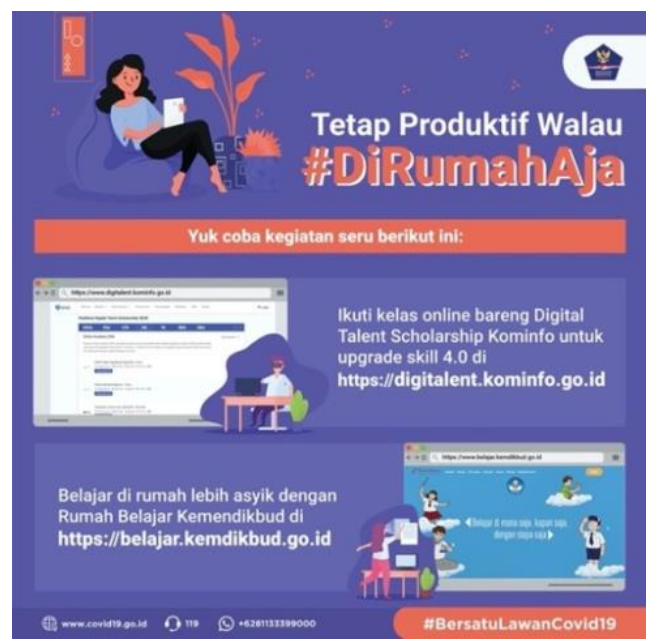

Gambar 3 Tetap produktif dirumah aja

Berbeda dari hasil konsep poster kampanye perilaku jaga jarak antar warga, Jakarta 50\% lebih fokus pada poster berkaitan dengan kampanye untuk tetap dirumah saja, dibandingkan dengan daerah Jawa Barat, Jawa Tengah, dan Jawa Timur. Jawa Barat dan Jawa Tengah lebih fokus pada kebiasaan gaya hidup sehat, sedangkan Jawa Timur poster lebih berkonsentrasi pada kampanye di rumah saja.

\subsection{Elemen Desain Poster Analisis Konten}

Poster harus dirancang untuk menarik perhatian dan mengomunikasikan informasi secara efektif. Enam elemen desain yang digunakan untuk menganalisis desain kampanye poster kesehatan sebagaimana dimaksud pada Gambar 4.
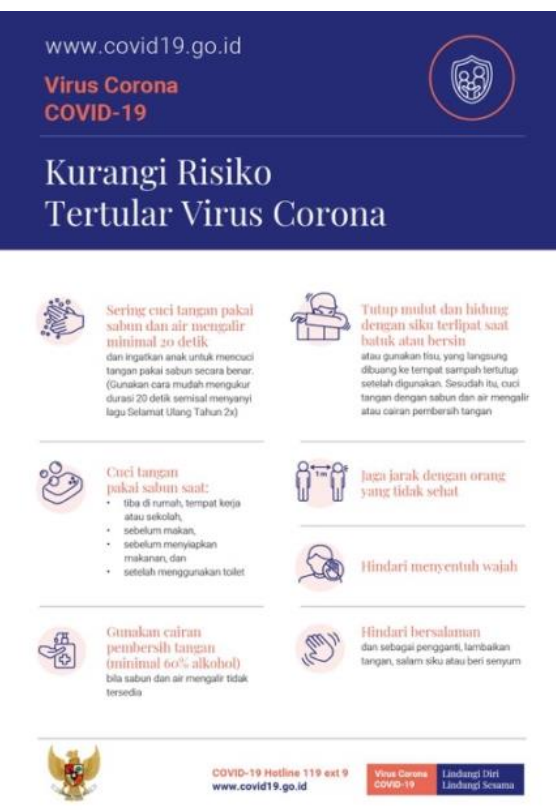

Gambar 4 Kurangi risiko terlular virus corona

Identifikasi unsur-unsur desain poster lokal dan nasional melalui kampanye poster berjalan terlihat pada gambar 4. Berdasarkan hasil analisis, $83 \%$ dari poster nasional menggunakan warna biru dan putih dengan penempatan konten yang rapi dan mudah dibaca. Sementara itu, poster lokal lebih suka mengaplikasikan warna cerah. Berdasarkan pada pandangan Hess, et.al (2013), maka desain poster lokal yang menggunakan warna cerah akan lebih menarik perhatian dan lebih indah dipandang. 
Pada Gambar 5, ditangkap semua info elemen desain poster berjalan lokal dan nasional.

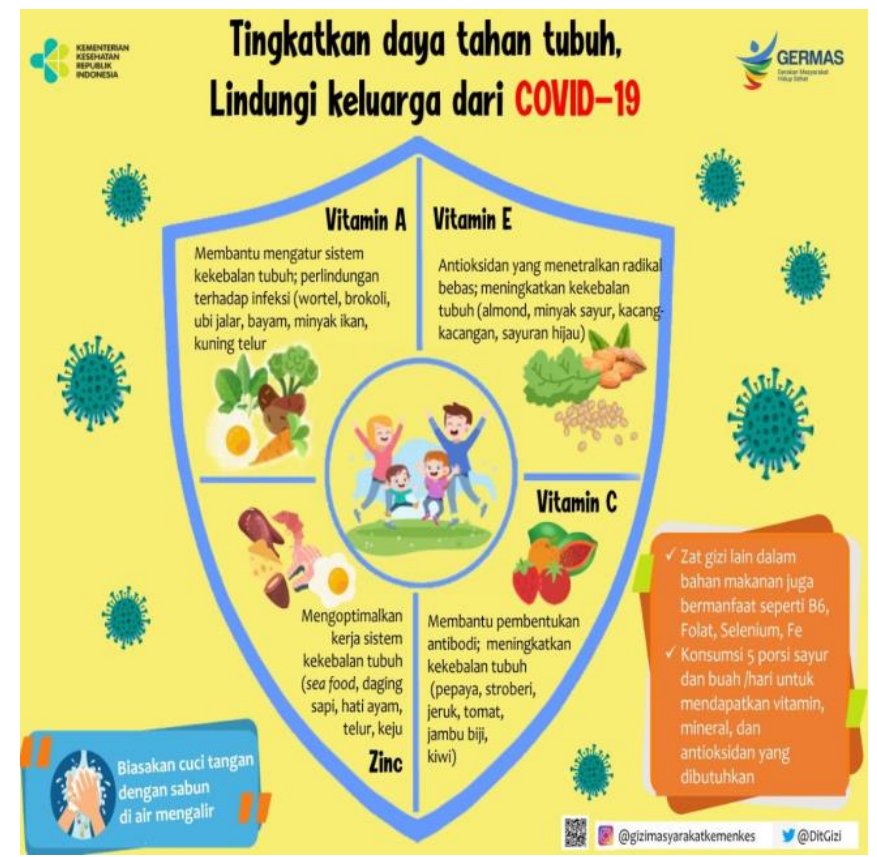

Gambar 5. Tingkatkan daya tahan tubuh, lindungi keluarga dari Covid 19

Untuk menganalisis ruang latar belakang, $67 \%$ poster lokal tidak memiliki ruang latar belakang, sedangkan poster nasional $100 \%$ menggunakan ruang latar belakang. Pada analisis judul, 67\% dari poster lokal menggunakan judul, sedangkan $100 \%$ poster nasional menggunakan judul.

Perancang national menggunakan $100 \%$ alat bantu visual vektor dalam poster pada gambar 4 , sementara perancang lokal hanya menggunakan setengahnya, seperti yang terlihat pada gambar 5. Alat bantu visual vektor menggunakan gambar (Sepupu, C, 2017), dapat berukuran dan diskalakan berulang kali, tanpa batas dan tanpa kehilangan resolusi atau mulai terlihat buram atau pecah pada saat ukuran poster dipilih berskala besar. Pada analisis konten poster lokal maupun nasional, persentase warna yang disukai lokal adalah warna cerah, sementara poster nasional menggunakan putih dan biru.

Penggunaan font, hanya 50\% dari poster nasional menggunakan jenis huruf San Serif, sedangkan poster lokal 100\% menggunakan San Serif. Berdasarkan kepada pernyataan dan pengamatan, poster pada gambar 5 mengeksplorasi berbagai jenis huruf terutama Serif. Lupton (2010) menyatakan bahwa desainer terkadang melanggar aturan ini. Font serif, jika fontnya besar dan dicetak tebal berakibat heading menjadi lebih bagus, gambar 4 memperlihatkan font serif yang digunakan cenderung terlihat serius dan penting, sedangkan pada gambar 5 membuat judul dan berita utama yang baik. Sans Seriffont bagus untuk blok teks kecil di sidebar atau dipanggil dari teks utama.

Hal lain yang membedakan poster lokal dan nasional lain adalah ukuran poster. Poster lokal sebagian besar dicetak dalam ukuran A1 $(59 \mathrm{~cm} \times 84 \mathrm{~cm})$, sedangkan pada poster nasional hanya $83,3 \%$ dari poster menggunakan ukuran A1, sisanya menggunakan ukuran 840 x 400 piksel untuk poster. Pada poster kampanye gaya hidup sehat gambar $4,66,7 \%$ poster lokal menggunakan alat bantu visual vektor dan menjadikannya sebagai alat bantu visual fotografi.

Analisis tertinggi ke-3 pada kampanye poster fisik melaporkan bahwa yang digunakan poster lokal $100 \%$ warna putih dan biru, sedangkan poster nasional hanya menggunakan 50\% warna cerah. Poster lokal maupun nasional memilih menggunakan 100\% San Serif sebagai font utama pada poster. Demikian juga untuk judul poster, kedua wilayah lokal maupun nasional memberikan judul lengkap di poster. Pembeda mendasar pada poster lokal maupun nasional adalah poster lokal tidak memiliki ruang latar belakang di poster rancangan. 


\section{SIMPULAN}

Pada tiga set analisis elemen desain poster lokal dan nasional sebagai digambarkan pada gambar 1 , 90\% dari poster lokal menggunakan warna biru dan putih sehingga terlihat mudah dibaca dan dimengerti. Hal ini didasarkan kepada pernyataan Perancang perspektif dari situs web Tips Desain Poster, bahwa dengan menambahkan latar belakang warna terang ke angka-angka dapat membuat poster menjadi menarik. Misalnya, menggunakan huruf putih dan garis-garis pada latar belakang biru menjadikan poster menarik sebagai konsistensi warna.

Seperti lukisan, elemen poster juga bisa melipat-gandakan simpulan secara fisik atau digital dengan menambah kontras pada poster. Poster desain lokal dan nasional menggunakan jenis huruf font San Serif. Menurut W. Author Brant (2015), dengan mendesain poster, situs web atau tulisan sebuah artikel, masyarakat akan lebih menyukai jika menggunakan font sesuai yang dapat dibaca dan menarik.

Jika dibandingkan dengan desain poster nasional, 83\% dari gambar 5 menggunakan ruang latar belakang dan poster yang lebih menarik. Desain poster lokal $100 \%$ menggunakan ukuran A1 $(59 \mathrm{~cm} x$ $84 \mathrm{~cm}$ ), sedangkan pada poster nasional hanya $20 \%$. Terakhir, desain poster nasional lebih fokus pada bantuan visual vektor dengan perbandingan $77 \%$ desain poster nasional, dan $67 \%$ desain poster lokal.

\section{DAFTAR PUSTAKA}

[1] Carter, E., \& DeNoon, C. (2008). Posters for the People: Art of the WPA. Quirk Books

[2] Cousins, C. (2017, September 20). Vector vs. Raster: What Do I Use? Retrieved March 25, 2018, from https://designshack.net/articles/layouts/vector-vs-raster-what-do-i-use/

[3] Cousins, C. (2017). Vector vs Raster: What Do I Use? Dilihat 25 Maret, 2018 dari Http://designshack.net/articles/layouts/vector-vs-raster-what-do-i-use/

[4] DeBara, D. (2018, January 29). How to design a poster: The ultimate guide. Retrieved March 26, 2018, from https://99designs.com/blog/marketing-advertising/how-to-design-posters/

[5] Girard, Scott dan Price, Marc A. (2012). Sales dan Marketing - Menjadi Marketer Andal dan Profesional. Solo: Metagraf.

[6] Hess, G., Tosney, K., \& Liegal, L. (2013). Creating Effective Poster Presentation and Effective Poster.

[7] https://www.covid19.go.id/kampanye/materi-edukasi-baru/

[8] https://manado.tribunnews.com/2020/04/04/30-gambar-poster-covid-19-atau-virus-corona-yang-cocokdibagikan-untuk-bahan-edukasi-di-medsos?page $=4$

[9] inspiredology.com/how-to-choose-between-serif-and-sans-serif-fonts/.

[10] Landa, Robin. (2013). Build Your Own Brand: Strategies, Prompts and Exercises for Marketing Yourself. HOW Books; Spi Edition

[11] Ladd, R. (2018, February 12). Designing Effective Posters. Retrieved March 26, 2018, from http://guides.lib.unc.edu/postersLanda, R. (2010). Graphic design solutions, Clifton Park, NY: Thomson Delmar Learning.

[12] Lupton, Ellen. (2010). Thinking with Type, 2nd revised and expanded edition: A Critical Guide for Designers, Writers, Editors, and Student.Princeton Architectural Press; Reviside, Expanded edition.

[13] Megawati. Pengaruh Media Poster Terhadap Hasil Belajar Kosakata Bahasa Inggris (Eksperimen di SDIT Amal Mulia Tapos Kota Depok). Jurnal Getsempena English Education Journal (GEEJ) Vol.4 No.2 (2017)

[14] “Poster Design Tips.” Learning Technology and Innovation, 2 Feb. 2017, 1ti.lse.ac.uk/poster-design-tips-2/.

[15] Retrieved January 11, 2018, from https://projects.ncsu.edu/project/posters/CreatePosterColors.html

[16] Tayebi, S. S. (2010). "The effectiveness of design elements like picture, text and color in aesthetic products

[17] Understanding visual hierarchy in poster design. (2016, August 08). Retrieved January 11, 2018, from https://99designs.com/blog/tips/visual-hierarchy-in-poster-design/ 
[18] Wilson, Author Brant. "How to Choose Between Serif and Sans Serif Fonts." Inspiredology, 15 Dec. 2015 ,

[19] "Advantages in Using Vector Graphics in Designing." Naldz Graphics, 8 Oct. 2016, naldzgraphics.net/vector- graphics-advantages/.

[20] Suryani, Anis. "Pengaruh Pendekatan Active Learning Metode Poster Comment Terhadap Hasil Belajar Ips kelas IV Di Sdn. Sunter Agung 11 Pagi Jakarta Utara (Jakarta : UIN Syarif Hidayatullah 2014) 